\title{
Assumptions concept of LEAN processes in the organization of the work on example the production of building components
}

\author{
Magdalena Mazur ${ }^{1}$ \\ ${ }^{1}$ Department of Production Engineering and Safety, Faculty of Management, Częstochowa University of Technology, al. Armii Krajowej \\ 19B, 42-200 Częstochowa, Poland, mazur.m@zim.pcz.pl
}

\begin{abstract}
The following paper discusses how to use of a company's assets efficiently by the identification of value stream and the elimination of all the processes that do not contribute to a company's added value. The identification of critical points of value stream by means of a map illustrating these processes helps to indicate the area where the selected elements of LEAN concept aiming at eliminating waste in domestic transport should be implemented. The article contains the analysis of the state of the current stream, and suggestions concerning its improvement.
\end{abstract}

Key words - LEAN Management, Value Stream Mapping (VSM), production of short series

\section{Introduction}

Lean Management (LM) is an instrument of strategic enterprise management which aims at achieving market success. The idea, which has been implemented and constantly improved by TPS (Toyota Production System), is primarily based upon the elimination of waste and muda. Muda ("futility; uselessness; wastefulness") refers to all the wastage caused by all the actions that do not contribute to a product's value, but, which, at the same time, consume its resources.

The aim of LM implementation is to use of the resources available and production potential in the most efficient way, and to shorten the process of fulfilling orders.

LEAN is a farfetched philosophy based on a longrange concept which sometimes works regardless of the fact that it does not produce financial results, at least the short-term ones. It also includes a commitment to long-term economic development of an organization over a longer period of time. Enterprises which attempt to implement LEAN concept make use of the most essential instrument intended to identify and minimize wastefulness, i.e., Value Stream Mapping (VSM) (INGALDI M. JAGUSIAK-KOCIK M. 2014).

\section{Streamlining of processes}

LEAN concept which uses of a variety of tools is a solution that makes it possible to create a flexible system which, at the same time, will be able to react quickly to any changes happening within and organization and its surroundings. The implementation of the concept in a company structure requires a constant improvement of such an organization through training 
designed for both, staff and employees. It also demands a division of duties and responsibilities by appointing small organizational units, or teams working on one particular task (CZERSKA J. 2009).

The improvement process of the whole enterprise in accordance with the premises of LEAN requires the use of all available tools and methods which are offered by management science. A necessary condition under which a proper transformation process will occur is their correct grouping, setting mutual connections, and utilising analysis results. Primary tools which facilitate creation of an efficient organization by using LEAN management concept include:

- Deming cycle (P-D-C-A) - a systematic series of actions occurring in a logical sequence which work in accordance with a basic concept of continual improvement of an enterprise functioning.

- Value Stream Mapping (VSM), whose aim is to collect data concerning the flow of goods and information.

- 5S - a tool for systematic learning of discipline, standardization, and striving for perfection.

- TPM - Total Productive Maintenance - a method aiming to provide a maximum number of mission critical production equipment. At the same time, it is a system which mitigates failures and improves quality due to involvement of all employees.

- SMED - Single Minute Exchange of Die - a method referring to changeover time reduction. It has a great significance in organizing manufacturing process and it guarantees system flexibility.

- KAIZEN philosophy - a tool jest that allows individual workers to organize and manage their work. It leads to devising standards for constantly improved processes.

\section{Process mapping in practice}

The presented analysis was conducted in a manufacturing and service company dealing with goods for construction industry and automotive industry working in SME and SMB sectors. The approach how to enhance efficiency of the company was developed according to its employees' experience and the premises of LEAN concept. The measures offered focused on waste elimination, which, according to Kaizen method, were supposed to be low-budget actions. Following
Toyota, in order to retain the morale in the research entity, one of the basic ideas before proceeding with the research was to leave the headcount intact (UlEwicz R., KuCĘBA R., 2016).

In order to implement lean management rules in terms of materials, mapping was performed so as to identify the status quo. The aim of this is to analyse the flow of goods according to "door to door" rule.

The analysis of a given value stream involves all the actions connected with a product undergoing a process form a basic feedstock to final recipients. The attempts to optimise material flow on an assembly line producing valves which are representative for the assortment. Figure 1 shows the current material flow.

Resulting from the effort of the staff and the analysis of the map illustrating the status quo, the main causes of waste were identified, i.e., excessive transport, redundant inventory, expendable movements, demurrage, improper manufacturing methods, as well as overproduction which leads to excessive strain (MURA). As based on prior experience, reasonable goals for lean manufacturing were defined:

- increasing the rate of inventory turnover,

- limiting the surface area of the production hall where spare parts inventory is located,

- limiting the number of workers engaged in the activity of moving materials within the area of the production hall,

- increasing the tact time of supplying stock parts to manufacturing cells,

- eliminating a need for engaging operators to move elements within the area of a production hall,

- reaching the level of $100 \%$ of planned production per shift as compared to the average production rate,

- eliminating the movement of forklift trucks supplying parts in the production hall.

In order to achieve the intended goals it was suggested that the size of product lot and flow units should be decreased between specific workstations which, consequently, will result in:

- increased flexibility, (the production time of one element is extremely short, the production of small series enables the system to react to customers' needs in a more flexible way and produce items which meet their expectations), 


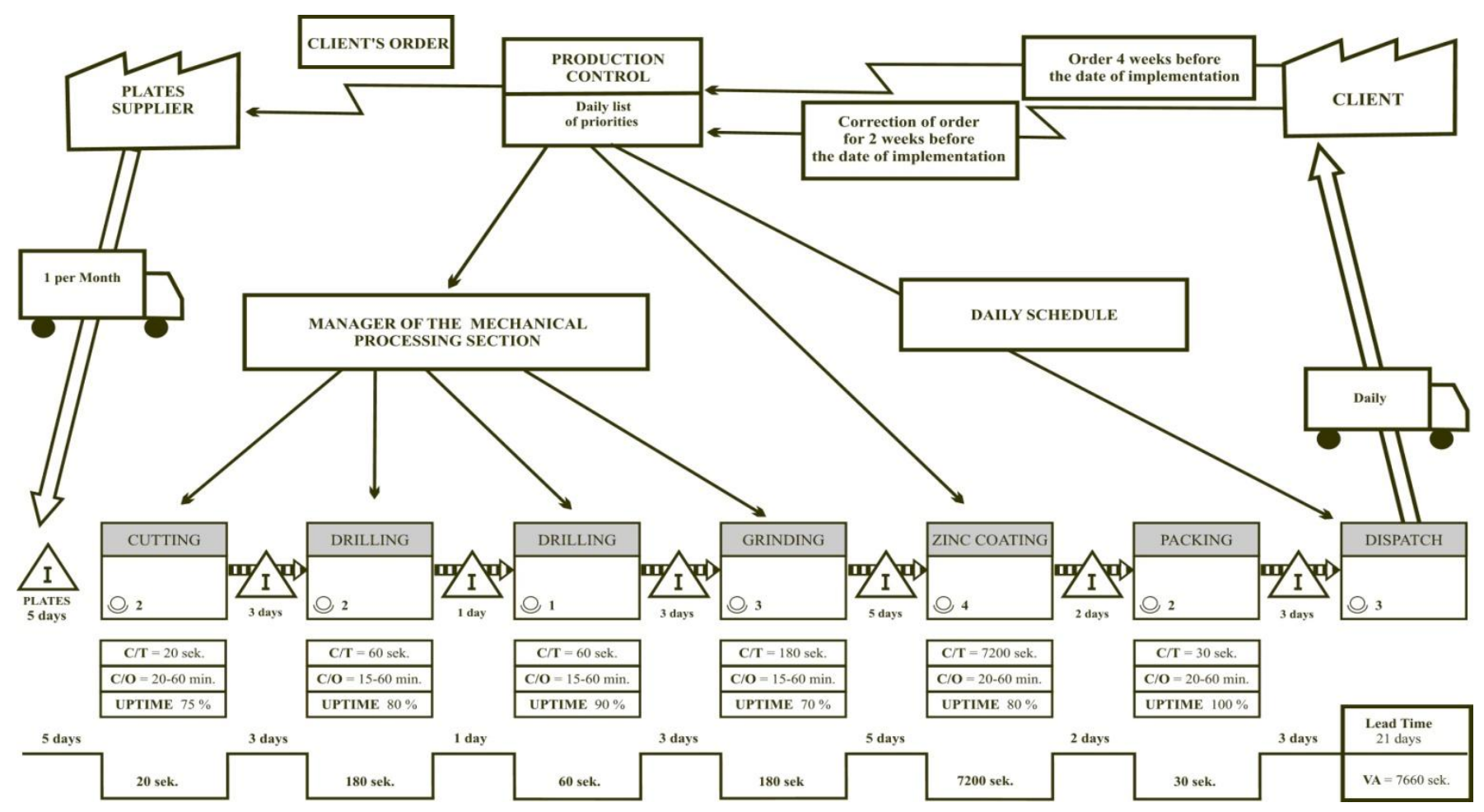

Fig. 1. The map of the current state of stream value for valve production.

- increased productivity (in case of short series flow cell, activities which do not add value are subjected to very definite standards),

- improved quality (incorporating quality within the flow of short series is much more efficient),

- creating additional production area (in a cell everything is situated in proximity and inventory occupies only a small space),

- safety improvement (smaller batches of elements are moved across the production hall, fork-lift trucks, which are the main cause of accidents, are eliminated),

- decrease in inventory costs.

\section{Results and discussions}

The methods of internal transport were thoroughly analysed. A fork-lift truck was eliminated due to its cost and the cost of its use, as well as the necessity of building wide paths along which it could move. A further argument for eliminating FLT in transportation process within a production hall is the fact that it carries full load boards, while parts in excessive number generate abundant inventory in the production process. Therefore, more cost-effective and more frequent supplies to manufacturing cells were suggested.
There were new manufacturing paths were designated (according to a rule which states that the width of oneway path is supposed to be $1.8 \mathrm{~m}$, while a two-way one $3.6 \mathrm{~m})$. For internal transport trucks with double steering axle were used. A crucial element is setting the manufacturing tact time enabling uninterrupted material flow through all the production processes avoiding the so called bottleneck.

The implemented suggestions concerning improvement and optimization of transport conditions within a company greatly contribute to a decrease in the risk level on the company premises which are linked to the elimination of fork-lift trucks from the production hall.

\section{Literature}

1. Czerska J. 2009. Doskonalenie strumienia wartości. Wydawnictwo Difin, Warszawa.

2. IngALDI M., JAGUSIAK-KocIK M. 2014. Lean tool used in the automotive industry. Production Engineering Archives, Vol. 4, No. 3, pp. 7-10.

3. UlewiCZ R., KuCĘBA R. 2016. Identification of Problems of Implementation of Lean Concept in the SME Sector. Economics and Management, Vol. 8, Iss. 1, pp. 1925 . 